\title{
Poesia alternativa além das palavras em Miró de Muribeca. A verdade da paisagem sem massagem \\ Jefferson Moura de Souza ${ }^{1 ;}$ Aleilton Santana da Fonseca ${ }^{2}$ \\ 1. Bolsista Fapesb, Graduando em Letras Vernáculas, Universidade Estadual de Feira de Santana, e-mail: Jefferson91moura@gmail.br \\ 2.Orientador, Departamento de Letras e Artes, Universidade Estadual de Feira de Santana, e-mail: $\underline{\text { aleilton50@gmail.br }}$
}

PALAVRAS-CHAVE: Poesia, Alternativa, Miró de Muribeca.

\section{INTRODUÇÃO}

O presente projeto de iniciação cientifica buscou estudar a obra poética de Miró da Muribeca, selecionando assim alguns poemas para análise e correlação das problemática levantadas, com a suas estratégias de escrita, atuação e divulgação. Buscou-se saber o que é "aquilo" que arremata a atenção ao ver o poeta em ação? De onde vem? Procurou-se entender as singularidades que fazem de Miró da Muribeca um poeta especial, possuidor de uma oratória poderosa, que descarrega séculos de opressões sob as lentes das câmeras, dilacerando, expondo aquilo que muitos não querem ver, numa linguagem popular, de fácil compreensão, com muitas imagens representativas da sociedade urbana ocidental em suas diversas problemáticas, sendo expostas paralelas a um olhar sensível sobre o mundo além do concreto ao seu redor. O projeto objetivou também, divulgar e estimular o debate em torno dessas problemáticas, assim como fomentar a performance e o ativismo artístico, como meio de se levantar esses debates.

\section{MATERIAL E MÉTODOS OU METODOLOGIA}

A metodologia é bibliográfica e áudio visual. Sendo assim, pesquisa a busca foi feita através da análise de vídeos com performances de Miró recitando seus poemas e do documentário de 2008 dirigido por Wilson Freire, intitulado: Miró: Preto, Pobre, Poeta e Periférico (todos no Youtube e com links disponíveis nas referências) tendo assim conhecimento da dissertação intitulada Corpoeticidade do Prof. André Telles (citada no documentário já referido), e da dissertação "Literatura marginal": os escritores da periferia entram em cena de Érica Peçanha do Nascimento. Foi lido também o livro Miró até agora (2016), que é uma compilação de quase todas as obras do poeta, Quem descobriu o azul anil (1985); São Paulo é fogo (1987); Ilusão de ética (1995); Flagrante deleito (1998); Quebra a direita,segue a esquerda e vai em frente (1999); Poemas pra sentir tesão ou não (2002); Pra não dizer que não falei do flúor (2004); Onde estará Norma (2006); Tu tás onde? (2007); Quase crônico (2010); dizCrição (2012). Para a execução dessa pesquisa não foi focada toda a obra do poeta, devido à sua extensão contraposta à abrangência de um projeto de iniciação cientifica, sendo assim, somente quatro poemas e um vídeo que podem atestar o encaixe desse autor dentro da pesquisa acerca das "Imagens Urbanas na literatura brasileira" serão consultados, e poderão sintetizar e simbolizar características marcantes do autor. e porque ele se mostra interessante e contribuinte ao eixo temático central do projeto. 


\section{RESULTADOS E/OU DISCUSSÃO}

Ficou explicito que o poeta Miró traz em sua obra um forte caráter performático, enraizado em uma ancestralidade trovadoresca. Sua literatura pode ser considerada marginal, por atuar fora do mercado editorial, e abordar contextos e temas que dizem respeito a uma minoria marginalizada por um contexto histórico opressor. Podemos notar em seus poemas muitas imagens peculiares do cenário urbano. Por ser o poeta um personagem das ruas de sua cidade (e do mundo), esse, acaba atuando como cronista, sentinela armado com o verbo em defesa de quem a muito não tem voz. O processo de pesquisa foi de fundamental importância para o começo de um aprofundamento sobre a literatura alternativa, permitindo assim que, na busca por materiais, num telefonema ao poeta, na produção do I Seminário de Literatura Marginal da UEFS, numa espera por um livro, o conhecimento fosse de forma interdisciplinar, se expandindo, e a literatura tomasse vida. A reunião desses materiais em torno do universo literário de Miró me permitiu conhecer mais poemas de Miró, recitando-o por qualquer praça, pondo em prática o que seus poemas incitam, "o corpo no poema, o poema no corpo". Os poemas de Miró pedem pra sair do papel, clamam por tomar vida entre braços e bocas, eis o maior resultado dessa pesquisa, a transformação que o contato com a obra de Miró proporciona na relação entre o poema e o corpo de quem recita, ele te faz repensar, no papel do corpo como forma de transmissão do que está no papel. Encoraja assim, subliminarmente, quem o vê em ação, a entrar em ação, soltar o verbo, sangrar no olhar.

\section{CONSIDERAÇÕES FINAIS (ou Conclusão)}

Após um longo ano de estudo mais atendo acerca da literatura marginal expressa performaticamente em Miró de Muribeca, pôde-se observar através da dissertação do professor André Telles do Rosário o trajeto histórico da arte da performance desde os tempos dos Trovadores onde não havia imprensa até os dias contemporâneos, desaguando na poesia expressiva de Miró, a tese de Érica Peçanha, iluminou o caminho no tratado sobre a problematização da terminologia de "literatura marginal". Essa leitura teórica associada à visualização de vídeos, e vivência da poesia de Miró na prática da recitação de seus poemas, proporcionada pela aquisição do livro Miró até agora, ocasionou a consciência da poesia enquanto uma arma de luta contra um processo de opressão histórica, sendo voz, e dando voz aos que devido aos disparates sociais foram calados por séculos. Temos nessa poesia uma carta bomba de um poeta que não observa a realidade expressa em seus poemas em terceira pessoa, muito pelo contrário, ele fala de algo que sente na pele, são imagens, vivas, pulsantes, quase em tempo real, e vista bem de perto. Fica concluso após investigação, conter na obra de Miró uma estreita relação entre tradição oral, performática e denúncias sociais expressas em recortes de imagens, ou cenas curtas, corridas, apressadas, como a vida urbana contemporânea. Assim se faz a obra de Miró, rápida, potente, como tiro, frenética como uma avenida cheia de bares, lojas, transeuntes sinais de trânsito e muitos prédios, porém mesmo em meio ao caos o poeta, num ônibus lotado, repara na cor do céu vermelho além dos prédios ao entardecer, lembra do sangue derramado na vala, na mesa sem pão... no moleque da biqueira. Mas mesmo pensando em tudo isso, não esquece de se emocionar ao entardecer da capital, e tal qual Drummond contempla a flor que nasce no asfalto. 


\section{REFERÊNCIAS}

ROSÁRIO, André Telles do. Corpoeticidade: Poeta Miró e sua literatura perfomática - Recife : O Autor, 2007.

NASCIMENTO, Érica Peçanha do. "Literatura marginal": os escritores da periferia entram em cena.- São Paulo 2006.

MIRÓ (Pseudo). SILVA, João Flávio Cordeiro. Miró até agora. Recife: 2016

MIRÓ: Preto, Pobre, Poeta e Periférico. Direção: Wilson Freire. Documentário, 19’35'”. Disponível em: https://www.youtube.com/watch?v=pncOPNB2qjc\&t=814s

ELZA caga na rua: Miró. Performance no programa DIVERSO: Poetas do Recife, 1'12', Disponível em: https://www.youtube.com/watch?v=_dl2DQE9Eb4 